\title{
ABSORPTION OF 2007-2015 EU FUNDING FOR UTILIZATION OF CULTURAL ASSETS IN RURAL AREAS IN SELECTED VOIVODSHIPS OF THE LOWLAND PART OF POLAND
}

\author{
Halina Poweska ${ }^{1}$, Post doctoral degree/ senior researcher \\ ${ }^{1}$ Warsaw University of Life Sciences -SGGW, Faculty of Economic Sciences
}

\begin{abstract}
The paper presents the problems of the financing of cultural heritage in rural areas through EU funds in selected voivodships (Wielkopolskie, Lodzkie and Lubuskie) of Central Poland in the years 2007-2015. It examines the structure and the level of differentiation of the utilization of EU funds for projects related to the protection and promotion of cultural heritage depending on the spatial category of beneficiaries: rural communes and small towns, which together are treated as rural areas (separate analyses were conducted for rural areas situated in the vicinity of agglomeration, and for those located outside the sphere of influence of the voivodship capitals), counties, cities with district rights as well voivodship capitals. The study used the database of the projects co-funded by the European Union, which is available in the National System for Information Monitoring and Control (KSI SIMIK 07-13) - information as of 31st December 2015. The paper shows that in rural areas the projects thematically related to the creation of a new tourism product and development of sports and recreation infrastructure played the dominant role, while in voivodship capitals and in urban areas most of the activities were carried out in the field of revaluation of cultural heritage objects.
\end{abstract}

Key words: rural areas, Polish Lowland, EU structural funds, cultural heritage.

JEL codes: Z32, Z19, P48

\section{Introduction}

In the past, agriculture was the main function of rural areas of the Polish Lowland, which is the central part of Poland. Today, the socio-economic development of this region is more diversified and it sees a dynamic development of non-agricultural functions (Adamowicz A., Zwolinska-Ligaj M., 2009). One of the major factors affecting this state of affairs is an important element of the neighbourhood and dynamic development of towns (Heffner K., 2016; Courtney P., Errington A., 2000). As a result, the main centres and cultural heritage assets are located in the towns and agglomerations of the Polish Lowland. However, cultural heritage objects and assets located in rural areas are also of great importance, since the fact that local communities may need to adjust their principles of life and management to environmental conditions contributed to the emergence of a specific culture of the region (Murzyn-Kupisz M., 2012).

Today, the maintenance of cultural heritage objects in good technical condition often exceeds the financial capacity of the local authorities; that is why the restoration and adjustment of these objects to new socio-economic functions (for example, tourism function) or the implementation of their own tasks (for example, education or administration) brings profits from both cultural and economic perspective. The renovated and restored cultural heritage objects, being the site of operation of the entities in museum education sector, stimulate the labour market and entrepreneurship. First, in the localities with a high cultural heritage potential there arise tourism products, which results in increased tourism movement. This is of great importance not only for the owners of accommodation and catering premises but also for the local trade, as well as for other activities directly or indirectly relating to the market supply of goods that are necessary to meet the needs of tourists (MacDonald R., Jollieffe L., 2003; Gralak K., 2009). Utilization of the restored cultural heritage objects for the implementation of administrative and social tasks promotes the integration of local communities and it positively affects the building of social and human capital of the region (Cawley M., Gillmor D. A., 2008). Thus, on the one hand, the activities aimed at the restoration and management of cultural heritage assets influence the state of preservation of these objects, and on the other hand, they stimulate socio-economic development in the local milieu. 
One way of financing the reconstruction and adjustment of cultural heritage assets to new socio-economic functions is the EU financial support (Poweska 2017). One way of financing the reconstruction and adjustment of cultural heritage assets to new socio-economic functions is the EU financial support. In the conducted studies, it was found that the implemented projects positively affected the standards of living of the residents in rural areas (Wojewodzka-Wiewiorska A., 2017; Wojewodzka-Wiewiorska A., Krievina A., Melece L., 2017). In the years 2007-2013 (2015)1, this source was utilized for culture-related purposes very rarely. According to the SIMIK database of the Ministry of Infrastructure and Development of the Republic of Poland, in the period 2007-2015 project financing agreements under the EU Structural Funds designed for cultural heritage projects across Poland amounted to less than $2 \%$ of their number and of the value of co-funding awarded. Despite their small share in a general amount of the EU financial support they had a significant effect on the cultural space of the regions.

The aim of the paper is to present the ways of spending of EU funds allocated for the purposes related to cultural assets in rural areas in selected voivodships of lowland Poland against a background of the remaining spatial categories. The study was conducted for the period 2007-2015 in three voivodships of the region: Lodzkie, Wielkopolskie and Lubuskie.

The article defines three research tasks:

- Investigation of the relationship between the overall value of the implementation of projects that are thematically related to culture and the amount of EU funding, depending on the spatial category of the regions;

- Definition of the goals on which EU funds were spent in rural areas in the Łódzkie, Wielkopolskie and Lubuskie Voivodships;

- Examination of the objectives of spending of the European "cultural" funds in rural areas in comparison with urban areas in the voivodships of Central Poland.

\section{Methodological assumptions}

European projects thematically related to culture were carried out under four Operational Programmes: Infrastructure and Environment, Human Capital, Innovative Economy and Technical Assistance. The analysis also comprised "cultural" projects implemented in the years 2007-2015 under the Regional Operational Programme for the Wielkopolskie, Lodzkie and Lubuskie Voivodships.

In this paper, cultural assets are understood in the sense included in the Law of 15th February 1962 (Ustawa o ochronie ... 1962). These are tangible and intangible goods, which are a historical and cultural legacy and which - due to their specificity and peculiarity - also play the role of transmitters of aesthetic and artistic values. Other factors playing this important role also include: landscape setting of cultural objects, their popularity, ways of promotion, spatial access, forms of their accessibility and the functions performed by the particular object.

The analysis conducted in the paper takes into account the following features of projects: thematic scope, total value and the amount of the EU co-funding, as well as an area in which the project was implemented. On the basis of a thematic scope of projects, five categories of purposes were distinguished: revaluation of cultural objects, creation of a new tourism product, sports and recreation infrastructure, promotion and others. Based on studies of literature (Rakowska J., 2013) and taking into account the specificity of the selected voivodships of Central Poland, the following

${ }_{1}^{1}$ Under the $\mathrm{N}+2$ role UE 2007-2013 may be spent by the of 2015 . 
spatial categories of beneficiaries were distinguished: rural communes and small towns, which together are treated as rural areas (rural areas situated in the vicinity of agglomeration and the areas located outside the sphere of influence of voivodship capitals were analyzed separately), counties, towns with district rights and voivodship capitals. The study was based on the statistical analysis method and the research findings were presented as tables and graphs.

\section{The survey area}

The Polish Lowland is a region whose cultural characteristics largely result from the historical influence of agriculture in the process of socio-economic development in the past. Conditions for the development of agriculture, in both the entire Polish Lowland and in the voivodships under study are fairly difficult. Predominance of poor and medium quality soils, mainly soil quality class of the 5th and 6th quality class, adverse and varied climatic conditions, drought periods interlaced with the periods of flooding, as well as frequent weather anomalies occurring in the region have adverse effects on the agricultural production process. At the same time, the lowland terrain, coupled with the absence of natural resources and raw materials, led to a great intensity of cultivation of the agricultural land in the past. Centuries-long tradition of farm management has resulted in high skills of the farmers in the field of farming culture.

At the same time, each of the voivodships under study retained its own specificity and diversity. The Wielkopolskie Voivodship is a leading area, in both the Polish Lowland and in the whole Poland, in terms of the efficiency and the level of global commodity agricultural production. However, the specificity of the Lubuskie Voivodship is the domination of forest areas (over $50 \%$ of its surface), hence the frequent game damage in the vicinity of forests, which adversely affects the agricultural production process. In the Lodzkie Voivodship, agriculture performs not only economic function but also: (1) social function, as a stabilizer and buffer of economic shocks, (2) cultural function because of the protection of tradition and regional and local identity as well as preservation of the rural landscape, and also (3) natural function including the protection of biodiversity or preventing soil erosion.

A very rapid agricultural transformation in the region has been observed over the past decade. Polish farmers using EU Assistance Funds modernized their farms; in many cases they increased the acreage of agricultural land, purchased agricultural equipment and machinery and built new livestock buildings. This led to increases in production levels and to an improvement in competitiveness in the European market. European Funds were also used to finance culture-related projects, which was analysed in this paper.

\section{Findings of the study}

In the years 2007-2015, the number of projects relating to cultural heritage assets carried out in Poland with the EU financial support amounted to $1678^{1}$. This constituted around $2 \%$ of European projects implemented in Poland in all thematic fields. It follows from the above that the potential of cultural heritage assets was not among the major purposes of the EU co-funded investments. Statistics relating to the cultural projects co-financed by EU funds and allocated to the Polish Lowland were similar. Altogether, in the Wielkopolskie, Lodzkie and Lubuskie Voivodships 158 agreements were signed and implemented; this constituted less than $10 \%$ of all cultural projects completed at that time. Most of the agreements were realized in the Wielkopolskie

${ }^{1}$ https://www.funduszeeuropejskie.2007-2013.gov.pl 
Voivodship, but here the value of the projects was relatively lower than that in the Lubuskie and Lodzkie Voivodships (Table 1).

Table 1

The number and the value of cultural heritage projects co-financed from EU funds in some voivodships of Lowland Poland in the years 2007-2015

\begin{tabular}{|l|c|c|c|c|c|c|}
\hline \multirow{2}{*}{ Specification } & \multirow{2}{*}{$\begin{array}{c}\text { Number of } \\
\text { projects }\end{array}$} & \multicolumn{2}{|c|}{$\begin{array}{c}\text { The total value of } \\
\text { projects }\end{array}$} & \multicolumn{3}{c|}{$\begin{array}{c}\text { Amount of co-funding from the EU } \\
\text { funds }\end{array}$} \\
\cline { 2 - 7 } & & total & for 1 project & total & for 1 project & \multirow{2}{*}{$\%$} \\
\cline { 2 - 8 } & total & \multicolumn{2}{|c|}{ Thousand EUR } \\
\hline Lodzkie & 25 & 76354.3 & 3054.2 & 46992.0 & 1879.7 & 61.5 \\
\hline Lubuskie & 16 & 74462.3 & 4653.9 & 25464.0 & 1591.5 & 34.2 \\
\hline Wielkopolskie & 117 & 148938.4 & 1273.0 & 78840.1 & 673.8 & 52.9 \\
\hline
\end{tabular}

Source: author's calculations based on KSI SIMIK 07-13 as of 31 December 2015

An average value of the cultural project completed in the Wielkopolskie Voivodship amounted to EUR 1.27 million, with the support of the EU funds totalling EUR 0.7 million, while in the remaining voivodships this value amounted to EUR 4.6 million and EUR 3.0 million, with the support from the EU budget amounting to EUR 1.6 million and EUR 1.9 million respectively. Projects of lower value were especially allocated to the local milieu, which is very important from the point of view of development of rural areas (Fig. 1).

Wielkopolskie Voivodship

Lodzkie Voivodship
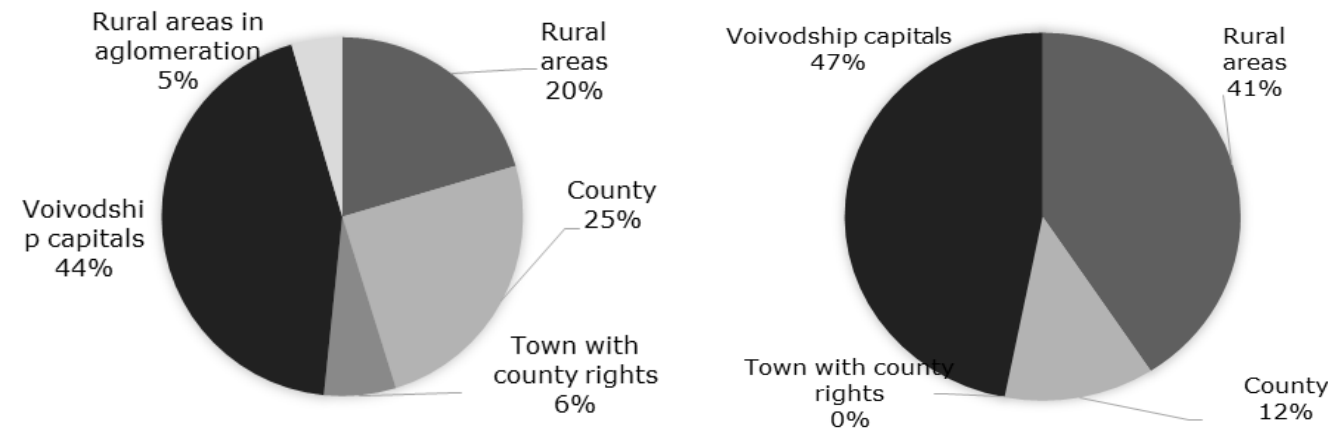

Lubuskie Voivodship

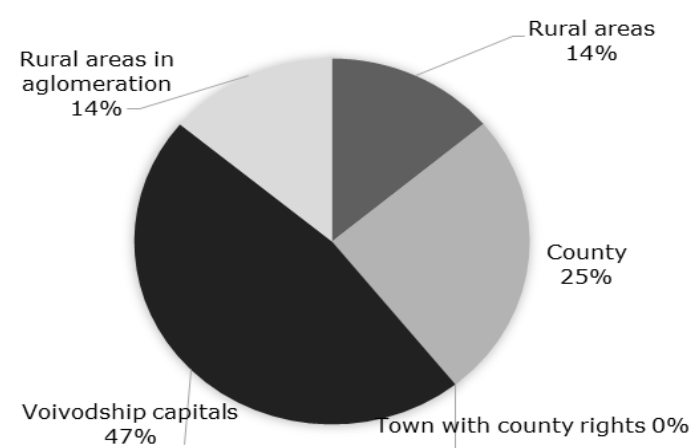

Source: author's calculations based on KSI SIMIK 07-13 as of 31 December 2015

Fig. 1. The structure of cultural heritage projects co-financed from EU funds in some voivodships of Lowland Poland in the years 2007-2015 by type in areas.

When analysing the structure of projects across regions, one should point to a clear domination of voivodship capitals, which, together with the adjacent areas situated in agglomerations, accumulated from almost $50 \%$ in the Lodzkie and Wielkopolskie Voivodships to more than $60 \%$ in the Lubuskie Voivodship of the value of EU co-funding for the European cultural projects completed over the 2007-2015 period. In rural areas, however, the largest amount of the EU grants for European projects was reported in the Lodzkie Voivodship (41\%), with $20 \%$ in the Wielkopolskie and $14 \%$ in Lubuskie Voivodship. 

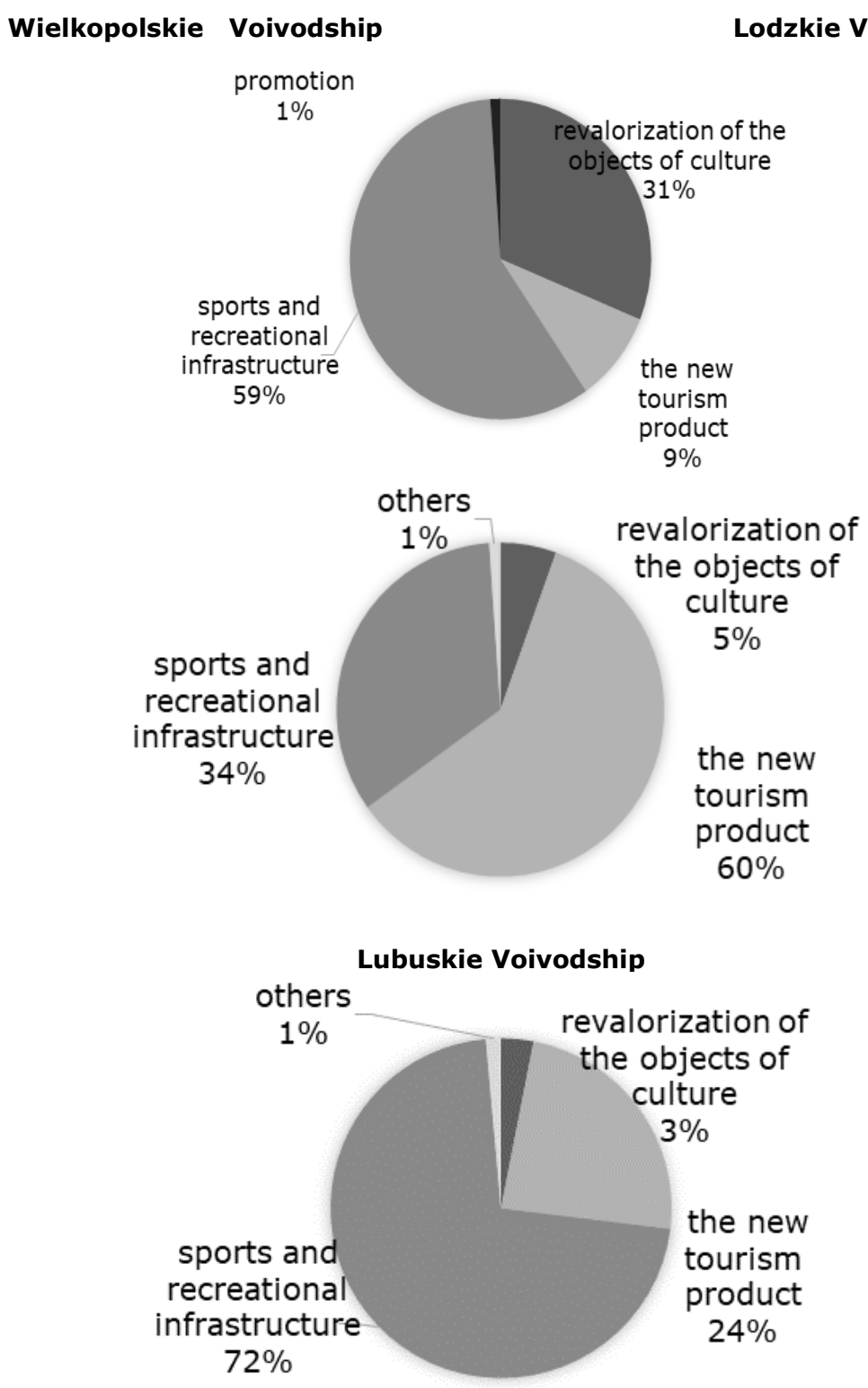

Source: author's calculations based on KSI SIMIK 07-13 as of 31 December 2015

Fig. 2. The structure of cultural heritage projects co-financed from EU funds implemented in rural areas in some voivodships of Lowland Poland in the years 2007-2015 by type of project

The analysis of the objectives of the projects implemented with the support of the EU grants and spent in rural areas shows differentiation between voivodships in terms of investments made using European funds (Fig. 2). The activities related to sports and recreation infrastructure were of great importance. In the Lubuskie Voivodship, as much as $72 \%$ of the EU funding was spent on this purpose. $59 \%$ was spent in the Wielkopolskie Voivodship and $34 \%$ in the Lodzkie Voivodship.

An average value of the cultural project completed in the Wielkopolskie Voivodship amounted to EUR 12.7 million, with the support of the EU funds totalling EUR 0.7 million, while in the remaining voivodships this value amounted to EUR 4.7 million and EUR 3.1 million, with the support from the EU budget amounting to EUR 1.6 million and EUR 1.9 million respectively. Projects of lower value were especially allocated to the local milieu, which is very important from the point of view of development of rural areas. 
The total value and co-funding from the EU funds of cultural projects cofinanced from EU funds in some voivodships of Lowland Poland by type of products and type of area

\begin{tabular}{|c|c|c|c|c|c|c|}
\hline \multirow{4}{*}{ Type of area } & \multicolumn{6}{|c|}{ Voivodship } \\
\hline & \multicolumn{2}{|c|}{ Wielkopolskie } & \multicolumn{2}{|c|}{ Lubuskie } & \multicolumn{2}{|c|}{ Lodzkie } \\
\hline & $\begin{array}{l}\text { The total } \\
\text { value of } \\
\text { cultural } \\
\text { projects }\end{array}$ & $\begin{array}{l}\text { Co-funding } \\
\text { from the } \\
\text { EU funds }\end{array}$ & $\begin{array}{l}\text { The total } \\
\text { value of } \\
\text { cultural } \\
\text { projects }\end{array}$ & $\begin{array}{l}\text { Co-funding } \\
\text { from the } \\
\text { EU funds }\end{array}$ & $\begin{array}{l}\text { The total } \\
\text { value of } \\
\text { cultural } \\
\text { projects }\end{array}$ & $\begin{array}{l}\text { Co-funding } \\
\text { from the EU } \\
\text { funds }\end{array}$ \\
\hline & $\begin{array}{l}\text { thousand } \\
\text { EUR }\end{array}$ & $\%$ & $\begin{array}{l}\text { thousand } \\
\text { EUR }\end{array}$ & $\%$ & $\begin{array}{l}\text { thousand } \\
\text { EUR }\end{array}$ & $\%$ \\
\hline \multicolumn{7}{|c|}{ Revalorization of the objects of culture } \\
\hline Rural areas & 10895.9 & 53.3 & 226.2 & 64.0 & 1773.0 & 68.0 \\
\hline County & 16288.8 & 63.5 & 3598.8 & 43.0 & 3423.4 & 53.6 \\
\hline $\begin{array}{l}\text { Town with } \\
\text { county rights }\end{array}$ & 3379.4 & 64.4 & 0.0 & & 0.0 & \\
\hline $\begin{array}{l}\text { Voivodship } \\
\text { capitals }\end{array}$ & 20763.5 & 64.3 & 3179.9 & 82.1 & 26957.4 & 71.1 \\
\hline $\begin{array}{l}\text { Rural areas in } \\
\text { agglomeration }\end{array}$ & 2314.0 & 53.8 & 1292.3 & 56.8 & 0.0 & \\
\hline \multicolumn{7}{|c|}{ The new tourism product } \\
\hline Rural areas & 3223.6 & 57.4 & 1763.6 & 43.5 & 19130.8 & 66.5 \\
\hline County & 3580.0 & 53.8 & 7774.6 & 29.4 & 3388.1 & 67.4 \\
\hline $\begin{array}{l}\text { Town with } \\
\text { county rights }\end{array}$ & 0.0 & & 0.0 & & 0.0 & \\
\hline $\begin{array}{l}\text { Voivodship } \\
\text { capitals }\end{array}$ & 38205.5 & 46.3 & 4751.9 & 40.93 & 7538.4 & 38.3 \\
\hline $\begin{array}{l}\text { Rural areas in } \\
\text { agglomeration }\end{array}$ & 1188.2 & 63.3 & 0.0 & & 0.0 & \\
\hline \multicolumn{7}{|c|}{ Sports and recreational infrastructure } \\
\hline Rural areas & 20460.0 & 39.8 & 5289.8 & 49.1 & 10873.6 & 45.9 \\
\hline County & 13386.2 & 46.3 & 5255.4 & 50.0 & 2916.6 & 56.8 \\
\hline $\begin{array}{l}\text { Town with } \\
\text { county rights }\end{array}$ & 3638.9 & 64.6 & 0.0 & & 0.0 & \\
\hline $\begin{array}{l}\text { Voivodship } \\
\text { capitals }\end{array}$ & 1623.8 & 32.46 & 35419.8 & 20.8 & 0.0 & \\
\hline $\begin{array}{l}\text { Rural areas in } \\
\text { agglomeration }\end{array}$ & 3709.9 & 42.7 & 5803.8 & 48.5 & 0.0 & \\
\hline \multicolumn{7}{|c|}{ Promotion and others } \\
\hline Rural areas & 382.1 & 84.5 & 106.0 & 29.9 & 353.2 & 71.0 \\
\hline County & 1439.6 & 83.7 & 0.0 & & 0.0 & \\
\hline $\begin{array}{l}\text { Town with } \\
\text { county rights }\end{array}$ & 639.2 & 83.9 & 0.0 & & 0.0 & \\
\hline $\begin{array}{l}\text { Voivodship } \\
\text { capitals }\end{array}$ & 4049.4 & 73.5 & 0.0 & & 0.0 & \\
\hline $\begin{array}{l}\text { Rural areas in } \\
\text { aglgomeration }\end{array}$ & 0.0 & & 0.0 & & 0.0 & \\
\hline
\end{tabular}

Source: author's calculations based on KSI SIMIK 07-13 as of 31 December 2015

It should be stressed that EU grants are particularly important for projects relating to renovation and revaluation of cultural heritage objects in rural areas of Great Poland. The effect of these investments is the improvement of cultural landscape in rural areas of this region. However, a very high share of spending on the development of sports and tourist infrastructure is a consequence of many years of neglect in this field in rural areas (Table 2). 
It was reported that the spending on the purposes related to the reconstruction of cultural heritage goods under culture-related projects was the highest, which can be seen especially in the Wielkopolskie and Lodzkie Voivodships. There, EU funding also amounted to $60 \%$ of the total value of projects. In the Lubuskie Voivodship, however, most of the EU funds received under culturerelated projects were spent on the development of sports and recreation infrastructure. While voivodship capitals spent most of the funds, beneficiaries in rural areas utilized from about $20 \%$ in the Wielkopolskie Voivodship to $30 \%$ in the Lubuskie Voivodship. Irrespective of the type of area and the voivodship, the highest EU financing was reported in the case of projects thematically related to promotion, where the co-funding amounted to $70-80 \%$ of the total value of projects. However, as regards the purpose of revaluation of cultural heritage objects, the highest funding was reported in voivodship capitals, regardless of the voivodship, and it ranged from 60 to $80 \%$ of the absolute value of the completed projects. When analysing the value of co-funding in the case of purposes comprising a new tourism product and development of tourism infrastructure, it should be noted that the largest EU grant was reported in rural areas and in rural districts where it ranged from 50 to $60 \%$ as compared to the level of co-financing ranging from 20 to $40 \%$ in urban areas. The towns with district rights were the only case where the co-financing exceeding $60 \%$ for projects relating to development of sports and tourist infrastructure was reported.

\section{Conclusions}

The analysis conducted in the study leads to the following conclusions:

- There are differences in the value of EU funding for culture-related projects carried out in the voivodships of the Polish Lowland over the period 2007-2015. The highest share - more than 60 percent - of EU funds in the total value of projects was reported in the Łódzkie Voivodship, while in the remaining voivodships this share amounted to 50 percent and 30 percent respectively in the Wielkopolskie and Lubuskie Voivodships;

- The analysis of the amount of EU funding for culture-related projects depending on the spatial category shows that in all the voivodships of the Polish Lowland much more funds were spent in urban areas (agglomerations, towns with county rights) than in rural areas (small towns, villages and rural districts);

- Among cultural projects implemented in the region and co-funded by the European Union major goals were related to the creation of a tourism product and the development of sports and recreation infrastructure, while in the voivodship capitals and in urban areas most activities focused on the revaluation of cultural heritage objects.

\section{Bibliography}

1. Adamowicz, M. (2009). Koncepcja wielofunkcyjnosci jako element zrownowazonego rozwoju obszarow wiejskich (The concept of multifuncionality as an element of sustainable development of ruralareas). Polityki europejskie, finanse i marketing. No. 2 (51 - T. 2). Warsaw: Wydawnictwo SGGW, 2009. p. 11-38.

2. Cawley, M., Gillmor, D.A (2008). Integrated Rural Tourism: Concepts and Practice. Annals of Tourism Research. Vol. 35, Iss. 2. pp. 316-33.

3. Courtney, P., Errington, A. (2000). The Role of Small Towns in the Local Economy and Some Implications for Development Policy, Local Economy, Vol. 15, Iss. 4. pp. 280-301.

4. Gralak, K. (2009). Funkcja turystyczna i jej znaczenie dla rozwoju lokalnego i regionalnego (Tourism function and its importance for local and regional development). In: H.Powęska (ed), Sposoby wykorzystania dobr kultury dla potrzeb rozwoju funkcji turystycznej na Mazowszu przy wsparciu z funduszy strukturalnych. Wydawnictwo SGGW, Warsaw, pp. 22-35.

5. Heffne,r K. (2016). Obszary wiejskie i małe miasta: czy lokalne centra sa potrzebne współczesnej wsi? (Small towns and rural areas. Do local centres needed by contempopary countryside?). Studia Ekonomiczne. Zeszyty Naukowe Uniwersytetu Ekonomicznego w Katowicach No 279. p. 11-22. 
6. MacDonald, R., Jolliffe, L. (2002). Cultural Rural Tourism: Evidence from Canada. Annals of Tourism Research. Vol.30. Iss. 2. pp. 307-322.

7. Murzyn-Kupisz, M. (2012). Dziedzictwo kulturowe a rozwoj lokalny (Cultural Heritage and Local Development).Wydawnictwo Uniwersytetu Ekonomicznego w Krakowie, Krakow, p. 350.

8. Powęska, H., 2017, Absorption 2007-2013(2015) EU funding for utilization of cultural assets in Dolnosląskie Province by spatial categories with specjal reference to rural areas. Roczniki Naukowe Stowarzyszenia Ekonomistow Rolnictwa I Agrobiznesu, T.XIX, z. 3. pp. 238-243

9. Rakowska, J. (2013). Klasyfikacje obdszarow - kryteria, definicje, metody delimitacji. Studium metodycznostatystyczne (Classifications of areas - criteria, definitions, methods of delimitation. Methodology and statistics). Wydawnictwo Wies Jutra. Warsaw. p. 142.

10. Ustawa o ochronie dobr kultury z dnia 15 lutego 1962. (Act of February 15 concerning the protection of cultural assets). Dz.U. 1962. Poz. 48.

11. Wojewodzka-Wiewiorska, A., Krievina, A., Melece, L. (2017). Building Social Capital Through Leader Approach 2007-2013: Case of Latvia and Poland. Proceedings of the International Scientific Conference Rural development 2017, Aleksandras Stulginskis University, Kaunas 2017. pp. 1-7, DOI: 10.15544/RD.2017.131.

12. Wojewodzka-Wiewiorska, A. (2017). The Importance of the Leader Programme 2007-2013 in the Rural Areas Development in Poland. Proceedings of the International Scientific Conference Research for Rural Development 2017. Vol. 2. (pp. 97-103). Jelgava, Latvia: Latvia University of Agriculture.

13. https://www.funduszeeuropejskie.2007-2013.gov.pl. The SIMIK database of the Ministry of Infrastructure and Development of the Republic of Poland. 